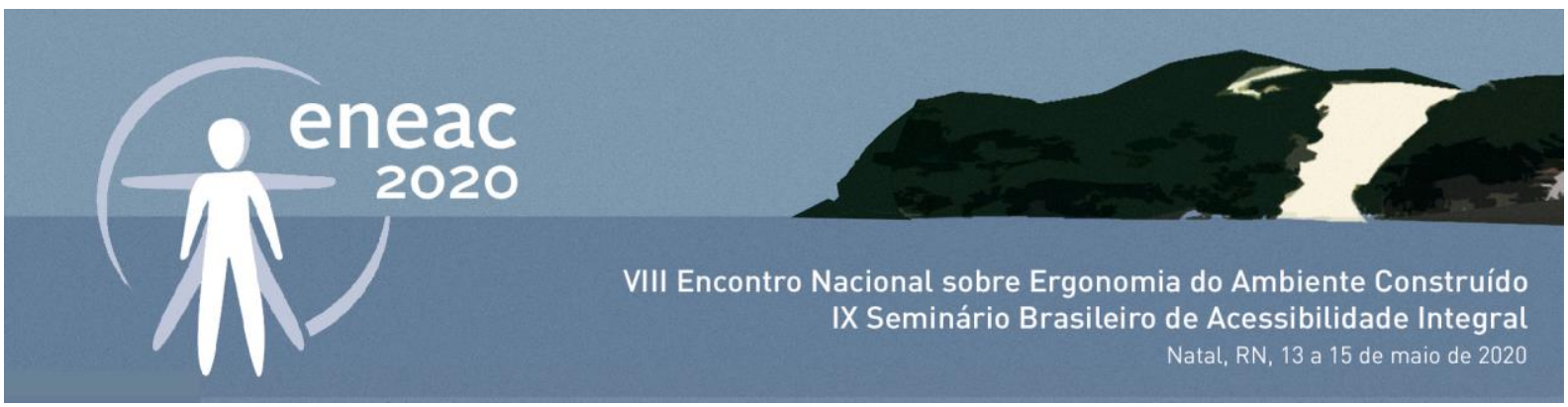

\title{
Habitação e envelhecimento ativo e saudável: a perspectiva de idosos
}

\author{
Housing and active healthy aging: the elderly perspective
}

\author{
CAROLINA MORGADO DE FREITAS SILVEIRA \\ Mestre, Universidade Federal de Santa Catarina, arq.carolinamorgado@gmail.com \\ VERA HELENA MORO BINS ELY \\ Doutora, Universidade Federal de Santa Catarina, vera.binsely@gmail.com
}

LIZANDRA GARCIA LUPI VERGARA

Doutora, Universidade Federal de Santa Catarina, I.vergara@ufsc.br

\section{RESUMO}

O crescente envelhecimento da população faz emergir preocupações quanto a propiciar maior qualidade de vida aos idosos. Ao estudar a inter-relação pessoa e sua habitação, este artigo tem como objetivo revelar atributos ambientais promotores de um lar confortável e aconchegante para o idoso. Para isso, adotou-se uma abordagem metodológica qualitativa de pesquisa, caracterizada por revisão bibliográfica e entrevistas com idosos ativos e saudáveis, de classe média e alta, residentes em região urbana. Os resultados revelaram como principais fatores para qualidade da residência para idosos: conforto ambiental e ergonômico, amplitude dos ambientes, contato com a natureza e a personalização dos ambientes. Além disso, é importante contemplar a relação com a cidade e a sociedade, particularmente quanto à proximidade aos familiares e aos amigos, bem como ao comércio e a serviços. As entrevistas demonstraram, também, que de forma geral, os idosos estão satisfeitos com a sua moradia e que, em um terço dos casos, as habitações já foram adaptadas às necessidades decorrentes do envelhecimento. As considerações finais espelham o número expressivo de atributos subjetivos relacionados à habitação. A pluralidade de percepções não proporcionou um consenso, porém possibilita a inferência de parâmetros que podem contribuir para desenvolvimento de projetos de habitações com ambiente acolhedor.

PALAVRAS-CHAVE: Arquitetura de habitação para idosos; Envelhecimento ativo e saudável; Relação pessoaambiente

\section{ABSTRACT}

The increase in the aging population raises concerns about providing a higher quality of life for the elderly. By studying the interrelationship between the person and their home, this article aims to reveal environmental attributes that promote a comfortable and cozy home for the elderly. For this purpose, a qualitative research methodological approach was adopted, characterized by literature review and interviews with the active and healthy elderly, of middle and upper class, living in urban areas. The 


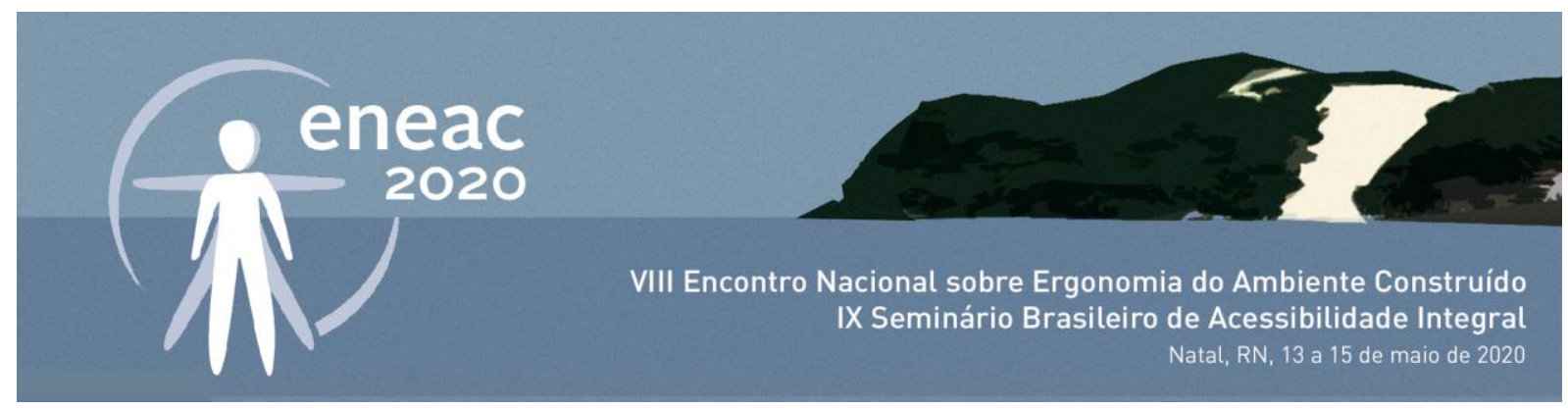

results revealed as main factors for quality of residence for the elderly: environmental and ergonomic comfort, amplitude of environments, contact with nature and environmental personalization. Besides, it is important to contemplate the relationship with city and society, particularly the proximity to family and to friends, as well as to commerce and to services. The interviews also showed that, in general, the elderly are satisfied with their housing and, in a third of the cases, their house has already been adapted to the needs arising from aging. The final considerations mirror the significant number of subjective attributes related to housing. The plurality of perceptions did not provide consensus, but it allows the inference of parameters that can contribute to the development of welcoming environment housing design.

KEYWORDS: Housing for the elderly architecture; Active and healthy aging; Person-environment relationship

\section{INTRODUÇÃO}

Anteriormente associado ao final da vida, o envelhecimento passou a ser compreendido como um fenômeno natural que não pode ser encarado como doença (CARADEC, 2016). O idoso é um ser humano que desfruta das conquistas alcançadas ao longo de sua existência, ao mesmo tempo que pode tornar-se mais sensível às doenças e à ocorrência de dificuldades de adaptação ao meio e aos novos desafios que se estabeleçam com o avanço da idade biológica.

Nesse contexto, verifica-se a habitação como o ambiente em que os idosos executam a maior parte de suas atividades e, também, corresponde ao local onde permanecem a maior parte de seu tempo (KALACHE, 2008). Tal fato baseia a relevância deste estudo, e, conduz à reflexão sobre a relação dos idosos com o ambiente residencial, evidenciando-se a importância e o significado da habitação em suas vidas. Portanto, tem-se como premissa o caráter reparador do lar quanto à manutenção e ao estímulo da autonomia, pois ao proporcionar um ambiente seguro e amigável, contribui-se para a qualidade de vida e para o bem-estar dos idosos (GITLIN, 2003; LEITH, 2006).

A interação pessoa-ambiente, focada no indivíduo que envelhece e a habitação, explorada na literatura acadêmica nos âmbitos da Arquitetura, Design e Ergonomia, frequentemente, relaciona-se aos idosos de saúde frágil ou com dependência. O cenário de escassez, no que tange aos idosos com autonomia e independência, motivou a realização de uma pesquisa maior, intitulada 'Habitação de suporte para idosos: contribuição da arquitetura para o envelhecimento ativo e saudável', desenvolvida para dissertação de mestrado no Programa de Pós-Graduação em Arquitetura e Urbanismo, da Universidade Federal de Santa Catarina. Derivado dessa pesquisa, o presente artigo centra-se no objetivo de identificar, por meio da perspectiva de idosos ativos e saudáveis residentes em área urbana, os atributos da configuração espacial da habitação que fomentam o seu conforto e bem-estar. Almeja-se, portanto, contribuir para a qualidade dos projetos de habitação para idosos, pois os resultados que transparecem as necessidades e anseios dos usuários correspondem a subsídios para a tomada de decisões inerentes ao planejamento arquitetônico. 


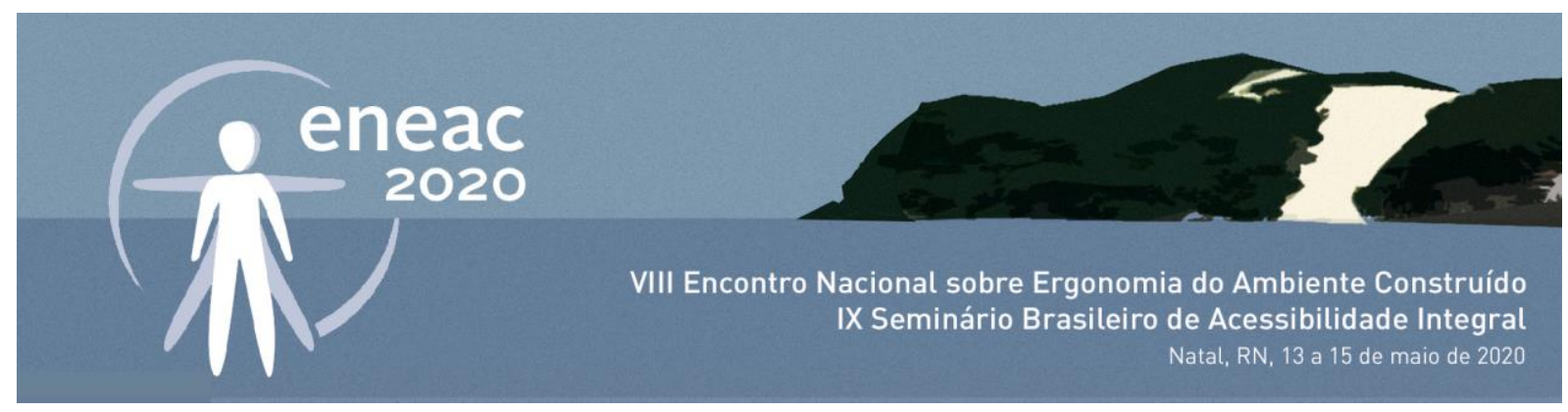

\section{ARQUITETURA HABITACIONAL E ENVELHECIMENTO}

No cenário nacional, há legislações que visam garantir o direito dos idosos, com destaque para o Estatuto do idoso que se alinha à Constituição Federal de 1988 - em que os direitos fundamentais inerentes ao ser humano aplicam-se a todos os brasileiros, a exemplo do direito à moradia e a ênfase nos princípios de autonomia, independência, participação, dignidade e autorrealização. Visão que se conecta à compreensão de que arquitetura e ser humano são indissociáveis, transparecendo um vínculo que permeia as diferentes fases da vida, e, que se fortalece com o passar do tempo.

Portanto, na contemporaneidade, há a valorização da qualidade da habitação, uma vez que se adequa ao anseio de garantir o envelhecimento ativo e saudável. Para a Organização Mundial de Saúde (WHO, 2015), o envelhecimento saudável abrange a conceituação ampla de saúde - entendida como completo estado de bem-estar - não se limitando apenas a ausência de doença ou de dor. Ao longo da vida podem ocorrer mudanças, mas deve-se preservar e maximizar a capacidade funcional do idoso, propiciando seu bem-estar físico, cognitivo e emocional. Há, portanto, o desejo de viver mais e com mais qualidade de vida (VALER et al., 2015), o que se conecta, também, ao conceito de envelhecimento ativo, processo que tem a intenção de otimizar as oportunidades contínuas de saúde, de segurança e de participação na sociedade quanto às questões sociais, econômicas, culturais, espirituais e civis (WHO, 2002; BRASIL, 2019). O termo envelhecimento ativo associa-se ao engajamento social em que as diferentes possibilidades de convívio devem ser promovidas, afastando-se da ideia de isolamento, vinculado ao advento da aposentadoria, ao recolhimento na intimidade do lar, e, ao falecimento de amigos e familiares.

Assim, arquitetos têm a oportunidade de propor soluções para o desafio do envelhecimento ativo e saudável. A orientação, de especialistas como Hunt (1991), é colocar o idoso no coração do projeto, pois ao centrar-se no usuário, visando maximizar suas habilidades, atender suas necessidades e expectativas, contribui-se para o seu bem-estar. Isso significa que os projetistas devem considerar que a habitação irá acompanhar as fases da vida das pessoas, e, portanto, deve adequar-se ao dinamismo e a pluralidade, afinal as pessoas e suas necessidades não são idênticas, e, a diversidade humana não é uma exceção (PYNOOS; CICERO, 2009). Conscientes do projeto centrado no usuário e do fato de que o ser humano envelhece desde o momento de seu nascimento, Masson e Vanneste (2015) destacam como questão norteadora ao arquiteto em seu processo criativo e de projeto: o suporte à vida, em que a habitação deve contemplar aspectos pragmáticos de suas características físico-construtivas, somado aos aspectos intangíveis que transparecem a subjetividade. A qualidade do projeto de residências para idosos está pautada no conceito de habitabilidade que se traduz em ambiente amigável que em sua totalidade atende as variáveis funcionais, simbólicas e técnicas espaciais, em coerência com as atividades a serem realizadas, bem como em adequação às necessidades dos usuários (MALARD, 2006).

\section{METODOLOGIA}

Nesta pesquisa de abordagem qualitativa, a metodologia utilizada inclui: revisão de literatura, entrevistas semiestruturadas e análise de conteúdo. A revisão de literatura acadêmica visou compreender e aprofundar referenciais teóricos relacionados ao tema, em que se elucidem conceitos básicos sobre a relação entre os idosos e a arquitetura habitacional. Para compreender as 


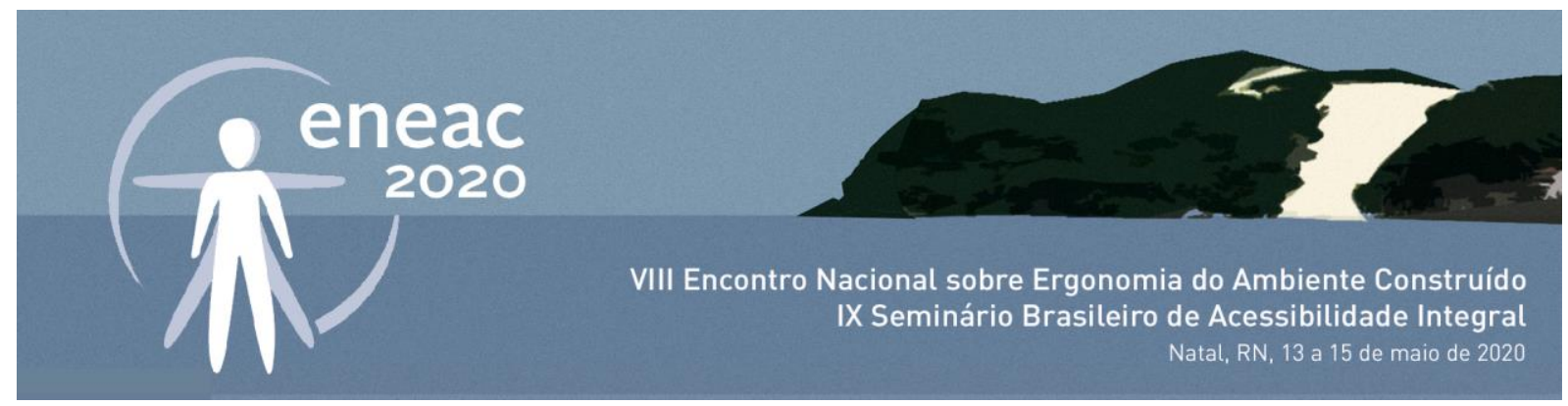

necessidades espaciais e a percepção dos idosos sobre a habitação, optou-se por entrevistas em que investigou o que pensam, sentem, fazem e esperam.

A pesquisa maior foi aprovada pelo Comitê de Ética da Universidade Federal de Santa Catarina, de acordo com o parecer número 2.047.149 (inscrição 63169316.0.0000.0121). A amostra não probabilística abrange 15 pessoas, cuja seleção foi orientada pelos seguintes critérios: pessoa com idade superior a 60 anos, com independência e autonomia, aposentada ou pensionista, pertencente à classe social $\mathrm{A}$ ou $\mathrm{B}$, que reside no município de Florianópolis, Santa Catarina.

As entrevistas foram realizadas de forma individual, em local escolhido pelo respondente, mediante o livre consentimento do participante. $O$ roteiro utilizado, como ilustra a Imagem 1, é dividido em duas partes. A primeira, investigou de forma objetiva o indivíduo e o contexto em que está inserido. A segunda, por meio de questões abertas, permitiu a liberdade de expressão sobre a percepção do lar.

Imagem 1 - Roteiro de entrevista

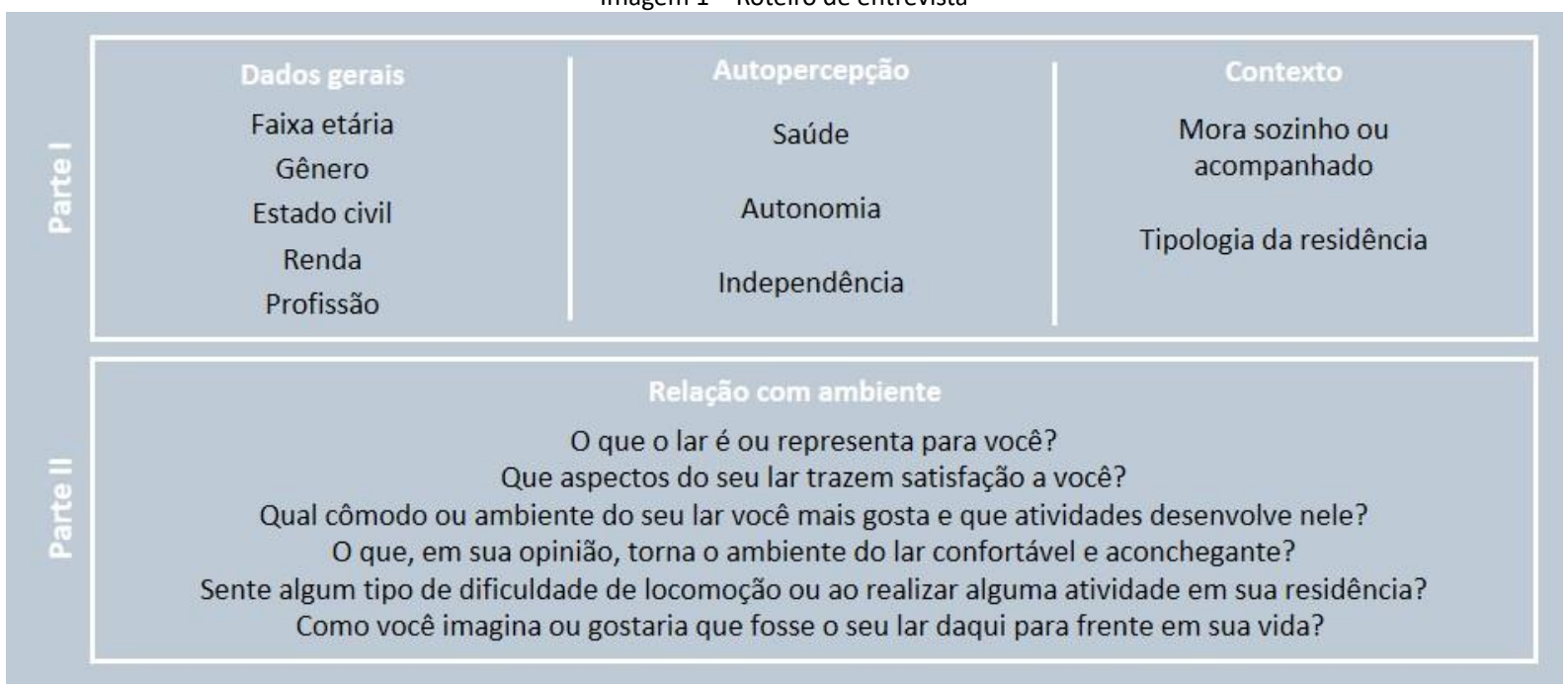

Fonte: Adaptado de SILVEIRA (2019).

A duração das entrevistas variou de 8 a 45 minutos, com média de 20 minutos. Para tratamento das informações, aplicou-se Análise de Conteúdo que possibilita explorar as transcrições, de forma que sua análise propicie o agrupamento dos resultados conforme similaridade (BARDIN, 2011).

\section{RESULTADOS E DISCUSSÕES}

Os dados coletados almejaram conhecer o perfil do público-alvo desta pesquisa: o idoso ativo e saudável, assim como a inter-relação pessoa e sua habitação frente ao processo de envelhecimento. Os principais resultados são expostos e discutidos na sequência, organizados em dois tópicos: (1) Caracterização geral e (2) Percepção sobre o lar. Para assegurar o anonimato, os depoimentos são apresentados utilizando sigla composta pela redução à primeira letra da palavra entrevistado, complementada por número que representa a ordem cronológica. 


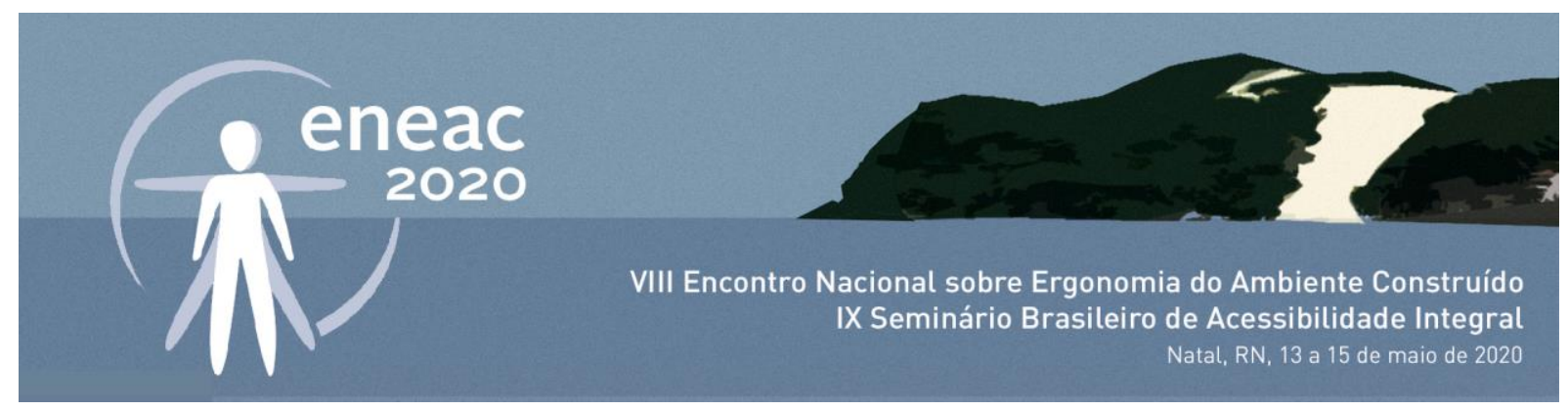

\subsection{Caracterização geral}

Com foco na inter-relação pessoa e ambiente, averiguou-se as características sociodemográficas dos entrevistados, somado a sua autopercepção de saúde, autonomia e independência. Além disso, investigou-se a tipologia da habitação em que reside, assim como a possibilidade de morar com outra pessoa, e, a ocorrência de quedas no ambiente domiciliar.

O Quadro 1 ilustra as considerações a seguir. A distribuição de faixa etária é heterogênea com predomínio das faixas 60 a 65 (4/15), e, 76 a 80 (3/4), enquanto as faixas de 66 a 70, 71 a 75, 81 a 85 e 86 a 90 equivalem a $2 / 15$ cada. 0 maior número de participantes é do gênero feminino correspondendo a mais da metade da amostra. Quanto ao estado civil, há o predomínio de indivíduos casados ou com união estável (8/15) - sendo duas mulheres e seis homens; seguido de viúvos (6/15) - sendo cinco mulheres e um homem; e há apenas uma idosa solteira. A maior parte dos entrevistados (9/15) possui renda familiar de 7 a 10 salários mínimos, enquanto $3 / 15$ estima renda acima de 20, 2/15 de 17 a 19, e, 1/15 de 11 a 13. A respeito da profissão, todos os entrevistados são aposentados ou pensionistas, porém três desses continuam no exercício profissional, desempenhando suas atividades por prazer, em um ritmo mais brando.

Quadro 1-Características sociodemográficas dos entrevistados

\begin{tabular}{|c|c|c|c|c|c|c|c|c|c|c|c|c|c|c|c|c|}
\hline \multicolumn{6}{|c|}{ Faixa etária } & \multicolumn{2}{|c|}{ Gênero } & \multicolumn{4}{|c|}{ Estado civil } & \multicolumn{5}{|c|}{ Renda (salários mínimos) } \\
\hline $\begin{array}{l}n \\
0 \\
0 \\
\varnothing \\
\varnothing\end{array}$ & $\begin{array}{l}P \\
0 \\
0 \\
0\end{array}$ & $\begin{array}{l}\stackrel{n}{N} \\
\sigma \\
\end{array}$ & 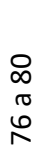 & $\begin{array}{l}n \\
\infty \\
\sigma \\
\infty \\
\infty\end{array}$ & 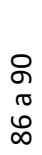 & 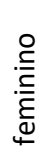 & 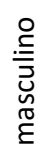 & 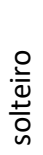 & $\begin{array}{l}0 \\
\frac{0}{0} \\
\tilde{J} \\
\tilde{J} \\
\end{array}$ & 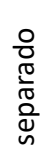 & 竞 & $\begin{array}{l}\stackrel{ }{न} \\
\text { గ } \\
\sim\end{array}$ & $\begin{array}{l}\stackrel{m}{7} \\
\sigma \\
\stackrel{-1}{-1}\end{array}$ & \begin{tabular}{l}
0 \\
-1 \\
$\sigma$ \\
\multirow{-}{+}{}
\end{tabular} & 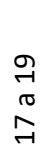 & $\begin{array}{l}\text { D } \\
\frac{d}{0} \\
\frac{n}{\pi} \\
\varepsilon\end{array}$ \\
\hline 4 & 2 & 2 & 3 & 2 & 2 & 8 & 7 & 1 & 8 & 0 & 6 & 9 & 1 & 0 & 2 & 3 \\
\hline
\end{tabular}

Em complemento à caracterização, investigou-se as condições de saúde, autonomia e independência dos entrevistados - ver Quadro 2. Para compreender o estado de saúde dos entrevistados, adotou-se como parâmetro a autopercepção, pois, segundo Confortin et al. (2015), é um bom indicador ao sistematicamente integrar componentes físicos, cognitivos e emocionais associados à noção de bemestar e à satisfação com a própria saúde. Foi questionado: "Em geral como você avalia a sua saúde? ", possibilitando-se quatro opções para resposta: ótima, boa, regular ou ruim. Resultados agrupados em positivo (ótima e boa) e negativo (regular e ruim).

Quadro 2-Condições de saúde, autonomia e independência dos entrevistados

\begin{tabular}{|c|c|c|c|c|c|c|c|c|c|c|c|c|}
\hline \multicolumn{6}{|c|}{ Saúde } & \multirow{2}{*}{$\begin{array}{c}\text { Autonomia } \\
\text { Protagonista } \\
\text { de sua vida }\end{array}$} & \multicolumn{6}{|c|}{ Independência } \\
\hline \multicolumn{4}{|c|}{$\begin{array}{l}\text { Autopercepção } \\
\text { de saúde }\end{array}$} & \multicolumn{2}{|c|}{ Doenças } & & \multicolumn{2}{|c|}{$\begin{array}{l}\text { Gerencia } \\
\text { finanças }\end{array}$} & \multicolumn{2}{|c|}{$\begin{array}{l}\text { Administra } \\
\text { medicações }\end{array}$} & \multicolumn{2}{|c|}{$\begin{array}{c}\text { Executa demais } \\
\text { atividades da } \\
\text { vida diária }\end{array}$} \\
\hline 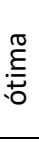 & $\begin{array}{l}\text { గ్ } \\
\text { ○ }\end{array}$ & $\begin{array}{l}\frac{\grave{T}}{\bar{T}} \\
\stackrel{0}{0}\end{array}$ & $\cdot \frac{\varepsilon}{\underline{1}}$ & $\frac{\varepsilon}{n}$ & 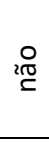 & 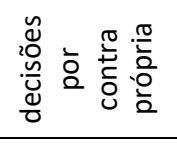 & $\begin{array}{l}\text { 온 } \\
\text {. } \\
\text { O } \\
\text { n }\end{array}$ & 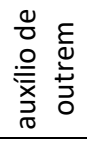 & $\begin{array}{l}\text { 을 } \\
\text { 甹 } \\
\text { O }\end{array}$ & 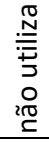 & $\begin{array}{l}\text { 을 } \\
\text { 足 } \\
\text { O }\end{array}$ & 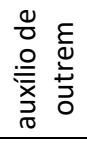 \\
\hline 4 & 7 & 4 & 0 & 9 & 6 & 15 & 14 & 1 & 12 & 3 & 11 & 4 \\
\hline
\end{tabular}

O maior número de idosos entrevistados tem autopercepção positiva, sete consideram sua saúde boa e quatro ótima. Somente quatro avaliam sua saúde como regular, e, nenhum participante concebe 


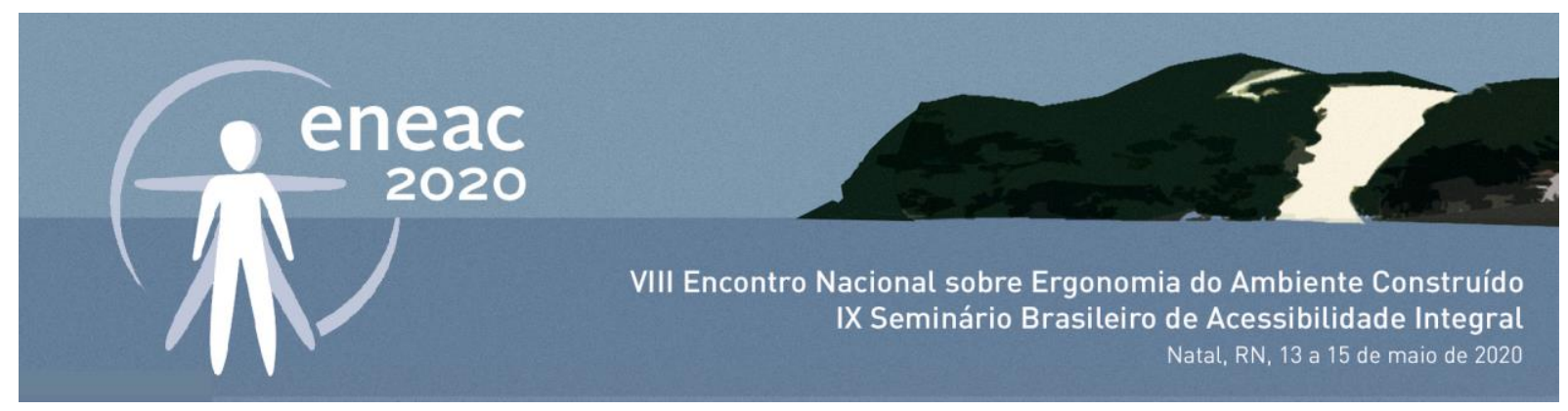

sua saúde como ruim. Foram enunciados como comprometimento da condição física, desequilíbrios orgânicos associados ao aparelho cardiovascular, esquelético e endócrino, a exemplo de: alterações da pressão arterial, bem como outras cardiopatias; osteoporose; lesões nos quadris, joelhos e coluna vertebral; e, ainda, hipotireoidismo e diabetes. Portanto, embora nove entrevistados tenham afirmado apresentar patologias, sua autopercepção de saúde expressou-se como positiva. Observouse a inclinação dos idosos na faixa etária entre 60 a 65 anos, com nenhuma ou apenas uma patologia, à autovaliação da saúde como ótima. Enquanto, aqueles em faixa etária entre 71 e 90 anos que apresentam de uma a três patologias, tendem a avaliar sua saúde como boa ou regular. Ao conectar essas informações, constata-se que o número de patologias pode influenciar, porém não é determinante para a autopercepção da saúde. Frequentemente o tratamento e controle de enfermidades permite um estilo de vida saudável ao longo do envelhecimento. Como evidenciado nas falas dos entrevistados desta pesquisa, a ausência de patologias no universo da saúde dos idosos é um privilégio de poucos, mas muitos são capazes de alcançar o completo bem-estar (RAMOS, 2003).

Ao investigar-se a autonomia e a independência dos entrevistados, evidenciou-se o consenso de total autonomia entre os participantes, uma vez que esses exercitam diariamente o controle sobre os rumos de sua vida. Nesse cenário, percebeu-se uma sutileza quanto à gestão financeira, em que a Entrevistada 03 declarou que, após o falecimento do esposo, delegou à sua filha essa atividade, outrora responsabilidade de seu esposo. Apesar da entrevistada não administrar sozinha suas finanças, não considera que sua autonomia esteja comprometida. A autonomia transpareceu-se, ainda, no planejamento de atividades a curto, médio e longo prazo, bem como na administração de medicações. Essa última, não faz parte da rotina de três entrevistados, pois não fazem uso frequente de medicações. Os demais doze participantes têm plena consciência da maneira, dias e horários adequados para a administração de medicações, sem carecer de auxílio de outrem. Além disso, os participantes afirmaram constatar o momento oportuno para agendamentos de consultas com profissionais da área da saúde, e, para a aquisição de medicações de uso contínuo. Verificou-se a unanimidade de independência dos entrevistados quanto ao desenvolvimento das atividades da vida diária. Contudo, três entrevistados relataram a necessidade de ajuda profissional no que tange a limpeza doméstica, e, outro participante além de empregada doméstica, dispõe de motorista diariamente. Para alguns participantes contratar serviços de limpeza ou de transporte não é sinônimo de dependência, considerando-os comodidades. Ao passo que outros participantes consideram a provisão de diarista uma necessidade de suporte de outrem. Situação que cogitasse estar relacionada a fatores culturais e econômicos, porque essas pessoas consideram a manutenção e limpeza da habitação como uma atividade integrante de sua rotina, que com o envelhecimento transformou-se em árdua ou equivalente a riscos de acidentes (HEYWOOD; OLDMAN; MEANS, 2002).

A caracterização relativa ao contexto que em que o idoso está inserido é apresentada no Quadro 3.

Quadro 3 - Entrevistados e o contexto em que estão inseridos

\begin{tabular}{c|c|c|c|c|c|c|c|c}
\hline \multicolumn{3}{c}{ Tipologia habitação } & \multicolumn{4}{c}{ Forma de morar } & \multicolumn{2}{c}{ Quedas e acidentes } \\
\hline $\begin{array}{c}\text { aparta- } \\
\text { mento }\end{array}$ & casa térrea & $\begin{array}{c}\text { casa de } \\
2 \text { pvtos. }\end{array}$ & sozinho & $\begin{array}{c}\text { com } \\
\text { cônjuge }\end{array}$ & $\begin{array}{c}\text { com } \\
\text { filhos }\end{array}$ & $\begin{array}{c}\text { com netos } \\
\text { sim }\end{array}$ \\
\hline 9 & 3 & 3 & 5 & 7 & 6 & 2 & 13 & 2 \\
\hline
\end{tabular}




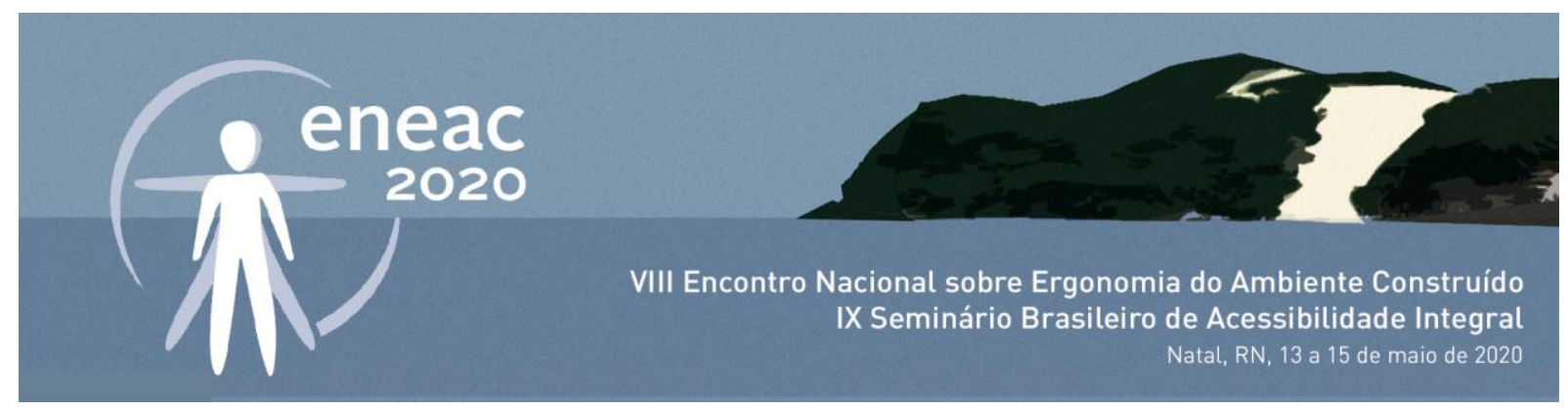

Sobressai-se a tipologia da habitação conhecida como apartamentos (9/15), seguido de casa térrea e casa de dois pavimentos ( $3 / 15$ cada). A maioria dos entrevistados mora com: companheiro ou cônjuge (7/15), filho (6/15), neto (2/15), e, 5/15 moram sozinhos. Há sobreposições desses grupos: três entrevistados residem com companheiro e filho, e, um com companheiro, filho e neto.

O coabitar revelou os vínculos familiares, em especial de indivíduos viúvos ou casados e, também, espelha a realidade contemporânea em que o idoso é provedor do lar, a exemplo do Entrevistado 10 que declarou: "O meu neto de 26 anos mora comigo". O morar sozinho mostrou-se associado ao estado civil: metade dos indivíduos viúvos; uma pessoa dentro do grupo dos casados, porém em processo de divórcio; e uma pessoa solteira. Do ponto de vista desses participantes, o morar sozinho não é interpretado como algo negativo, como ilustra a declaração da Entrevistada 05: "Nunca casei, nunca tive filho. Existe diferença entre solidão e solitude. Hoje eu sou a minha melhor companhia". Isso é, viver só não significa viver isolado, evidenciando-se a participação social dos entrevistados, em particular em grupos de idosos ou de trabalho filantrópico. Além disso, os participantes expressaram o gosto por viajar, receber e hospedar amigos e familiares.

Por fim, delineando-se um elo entre a saúde do entrevistado e a segurança do ambiente residencial questionou-se a ocorrência de quedas. Dois entrevistados afirmaram ter vivenciado esse tipo de situação, em três principais ações: tropeçar em fios soltos, tentar pegar objetos acima do alcance confortável, e, piso externo molhado. O perigo de objetos não fixados em áreas destinadas ao fluxo de pessoas espelha-se no depoimento: "[...] Uma vez que a faxineira deixou o aspirador no corredor, eu tropecei no fio, cai e bati com meu rosto no chão" (E13). O segundo e terceiro caso podem ser expressos em: "Um dia estava no pátio com a mangueira na mão, acabei escorregando [...] quebrei a bacia e cóccix [...] outro dia, subi em cima de uma cadeira de plástico que tinha na cozinha, a cadeira quebrou, ao cair me apoiei no forno elétrico que estava ligado [...]" (E15).

Além do ambiente residencial, dois participantes compartilharam experiências de quedas em virtude de falhas de projeto ou execução, dentre elas elencaram características técnicas de revestimentos e o dimensionamento de desníveis. Tais observações são explanadas em: "Já caí na rua, ocorreu numa descida molhada, em dia de chuva" (E12); e, "Em casa não, só na rua e no hotel [...] um dos tombos que eu levei foi em uma escada malfeita, tinha um degrau bem alto e outro baixo" (E11). Assim, reconhece-se a inadequação de ambientes às possíveis limitações funcionais dos idosos, ao não propiciar conforto e segurança, afeta a saúde do idosos e contribui para a ocorrência de acidentes (HEYWOOD, 2004). A recomendação de projetos que evitem acidentes se lastreia tanto na representação de um evento limite, que pode culminar em estado de fragilidade, de dependência, ou de possível institucionalização e falecimento; quanto na prevenção de consequências emocionais negativas devido ao medo de novas quedas (OLIVEIRA et al., 2014).

\subsection{Percepção sobre o lar}

A segunda parte do roteiro de entrevista diz respeito às perguntas abertas acerca da percepção pessoal sobre o lar. Acredita-se que compreender como as pessoas percebem o espaço com o qual interagem cotidianamente permite conhecer as suas necessidades espaciais, requisito fundamental para propiciar uma ambiência acolhedora, efetivamente segura e confortável a fim de garantir a independência dos idosos (BINS ELY, 2009 e 2017).

No desenvolvimento das entrevistas evidenciou-se a dificuldade das pessoas em expressar as sensações oriundas de sua relação com a arquitetura da habitação. Seguindo a recomendação de 


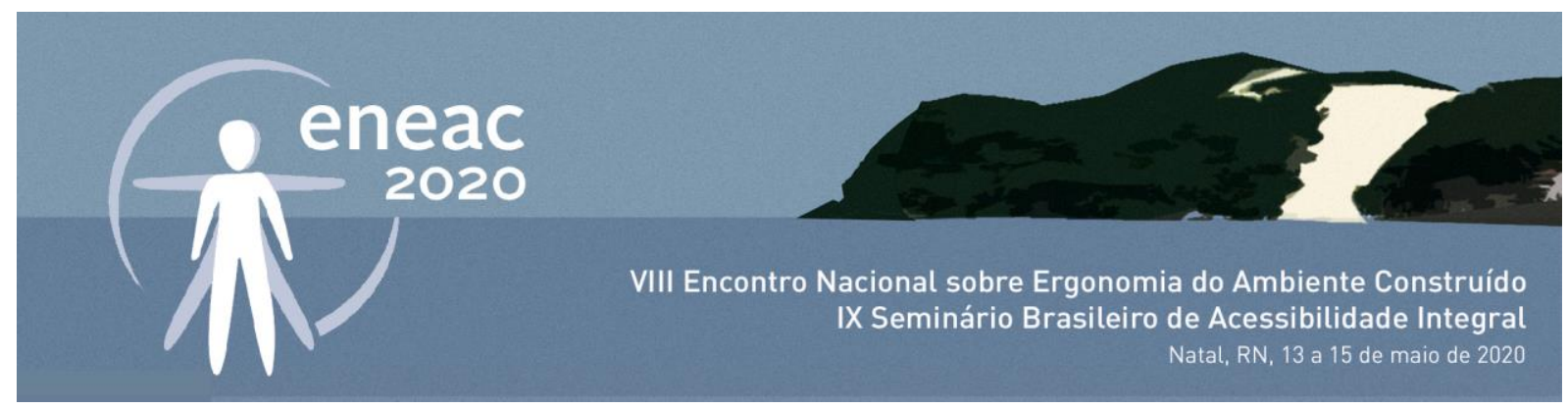

Rheingantz et al. (2009), extraiu-se da linguagem verbal as nuances e subjetividades, aflorando-se cinco categorias: Significado, Preferências, Atividades, Conforto e Futuro, elucidadas na Imagem 2.

Imagem 2 - Categorias de acordo com Análise de Conteúdo

\begin{tabular}{|c|c|c|c|c|}
\hline Significado & Preferências & Atividades & Conforto & Futuro \\
\hline $\begin{array}{l}\text { compreensão } \\
\text { do que o lar é } \\
\text { ou representa }\end{array}$ & $\begin{array}{c}\text { aspectos da } \\
\text { habitação que } \\
\text { trazem } \\
\text { satisfação }\end{array}$ & $\begin{array}{l}\text { o que mais gosta } \\
\text { de fazer em sua } \\
\text { residência, e } \\
\text { dificuldades que, } \\
\text { porventura, } \\
\text { encontre }\end{array}$ & $\begin{array}{l}\text { aspectos que } \\
\text { tornam a } \\
\text { residência } \\
\text { confortável e } \\
\text { aconchegante }\end{array}$ & $\begin{array}{c}\text { maneira como } \\
\text { antevê a } \\
\text { habitação em } \\
\text { seu próprio } \\
\text { futuro }\end{array}$ \\
\hline
\end{tabular}

Fonte: Autoras (2019).

\subsubsection{Significado}

A categoria Significado investiga o conceito e a representação de lar, de acordo com a perspectiva dos entrevistados. Dentre os depoimentos destacam-se três principais significados: abrigo, bem-estar e família. Resultado alinhado com o ponto de vista de Brandão e Heineck (2003), em que a habitação é compreendida além do núcleo territorial ou organização espacial, envolvendo aspectos de multidimensionalidade e de dinamismo inerentes ao ser humano.

Das subcategorias evidenciadas, a percepção de abrigo refere-se à essência da arquitetura, o que se espelha nas sensações de acolhimento, aconchego e refúgio. A noção de bem-estar, se transparece nos sentimentos de liberdade, tranquilidade, harmonia e descanso. Cenário que pode ser ilustrado pelas falas: "É um refúgio, é [...] onde a gente tem o bem-estar geral" (E11); e "Eu acho que é um porto seguro, um lugar onde a gente se sente em segurança, se sente acolhido e tem autonomia para fazer as coisas [...] é algo que tu podes desfrutar no momento que tu quiseres" (E01).

Como indica Bachelard (2000), a habitação é uma composição geométrica que se conecta à metáfora de ninho, espelhando o acolhimento do corpo e da alma. Isso, ao ser entendida enquanto extensão das emoções humanas, transparecendo a vida e a cultura de seus moradores (SCHMID, 2005). A habitação, portanto, é uma edificação destinada ao abrigo do indivíduo e de seu grupo familiar, revestindo-se também de características subjetivas (ELALI, 2006). A dimensão familiar foi verbalizada em expressões como união e convivência familiar, exemplificada em: "lar representa um fator agregante da família. O homem nasceu para ser gregário, não nasceu para ser sozinho"(E10).

\subsubsection{Preferências}

Nesta categoria observa-se pluralidade de percepções, cujas principais caraterísticas da habitação associadas às preferências referem-se à implantação da edificação, bem como à sua orientação solar, aos materiais de construção e de revestimentos, às dimensões, dentre outras peculiaridades. A seguir, tal cenário é apresentado em duas subcategorias: fatores positivos e fatores negativos.

Na subcategoria fatores positivos, primeiramente, aborda-se os ambientes preferidos que correspondem àqueles de maior tempo de permanência, a exemplo de: sala, home office, cozinha e dormitório. Parte do setor social da residência, a sala "é onde a gente recebe os amigos [...] senta e 


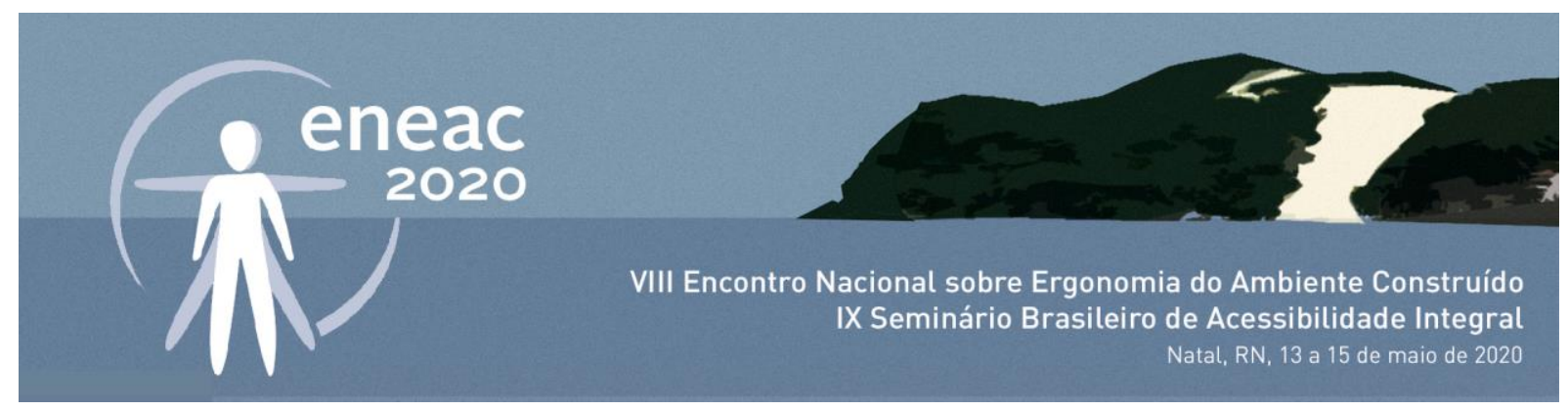

conversa, vê televisão" (E06). Palco para a realização de diferentes atividades de trabalho e que, ao mesmo tempo, é considerado um espaço privativo, revelam-se os home offices, como evidencia a fala "Eu gosto muito do ateliê [...] lá é o meu espaço" (E02). Esse espaço também é compreendido como aquele que possibilita o convívio com familiares e companheiro(a), como grifa o Entrevistado 15 "Tenho o meu escritório e ali minha esposa executa suas tarefas manuais, assim, estamos sempre perto". Já os prazeres da gastronomia, da comensalidade e do aconchego emocional são relatados em: "Eu acho agradável a cozinha [...] a gente fica sentado à mesa, tem uma coisa no fogo cozinhando [...]" (E12). O ambiente mais mencionado quanto ao setor íntimo da residência é o dormitório, que é interpretado como local para relaxamento, como atesta o Entrevistado 01: "[...] Ali eu posso descansar [...] tenho o meu sossego" (E01). O dormitório conecta-se, ainda, às memórias espelhadas na fala: "[...] meu quarto, lembra muito o meu marido, nós vivemos 55 anos juntos" (E15).

Os principais indicadores de preferência são: relação com a natureza; amplitude; privacidade; controle e personalização. $\mathrm{O}$ apreço pela presença de elementos naturais e o contato visual com a paisagem natural transparecem em: "Eu gosto [...] de ter umas folhagenzinhas" (E01); "O que me dá muita alegria são os janelões [...] por eles eu vejo os pássaros nas árvores" (E05); e "Não gosto quando constroem prédios para tirar a nossa vista para o mar" (E12). A relação ser humano e natureza promove bem-estar e qualidade de vida pois, ao estimular os sentidos, dentre outros benefícios reduz do estresse, e, contribui para o escape cognitivo, relaxamento e lazer contemplativo (SHRAIKY, 2011). A predileção por espaços amplos e que assegurem a privacidade podem associar-se ao status social e às experiências anteriores, como ilustram as falas: "Nós gostamos, de ambientes amplos [...] ele [esposo] tem um canto para ele, tem a privacidade dele para isso" (E11); e "A casa é mais do que apenas um quarto [...] em que eu não fique limitada por quatro paredes" (E02). Nessas verbalizações há implícito juízo de valor, pautado na comparação entre experiências vividas. Além disso, alinhado ao pensamento de Sommer (1973), constata-se a inclinação das elites por espaços de maior área e qualificação, fato observado na amostra desta pesquisa, em que os entrevistados pertencem às classes sociais que são economicamente privilegiadas.

A cultura é um importante elemento a ser considerado no planejamento de edificações, porque relaciona-se tanto com aspectos objetivos como o dimensionamento e integração espacial, quanto com aspectos subjetivos. Nesta pesquisa constatou-se a cultura espelhada na habitação por meio dos hábitos cotidianos e personalização espacial, o que se conecta à liberdade de escolha dos entrevistados devido ao seu poder aquisitivo. Dentre os elementos subjetivos, a privacidade foi enaltecida nas entrevistas. Influenciada por diferentes atributos da ambiência, a privacidade visa, quando desejado, assegurar o anseio de ficar só ou de afastar-se do convívio social. Há o senso de controle (ULRICH, 1991) em que a pessoa tem autonomia para interação interpessoal ou a negação dessa e, também, propicia a auto regulação da exposição - o quanto de si e/ou de um ambiente pode ser visto por outrem. A subjetividade também se revela quanto ao apego ao lugar, conceito compreendido como vínculo afetivo entre indivíduo e ambiente, que pode ser expresso em representações de valor simbólico associado ao bem-estar e a qualidade de vida (GIULIANI, 2004). Dentre as entrevistas, destacam-se as verbalizações que valorizam o caráter único e especial da habitação, constatando-se que tal afeição é reforçada à medida que o ambiente é apropriado pelo indivíduo, favorecendo seu sentimento de acolhimento, proteção e segurança. Quadro que é ilustrado em: "Gosto de deixar o meu lar agradável para as pessoas que eu recebo [...] mas o apartamento tem que ser do meu jeito [...]" (E05). Por essa razão, arquitetos como Hertzberger (1999) consideram o projeto de ambientes como um convite para que o usuário complemente os 


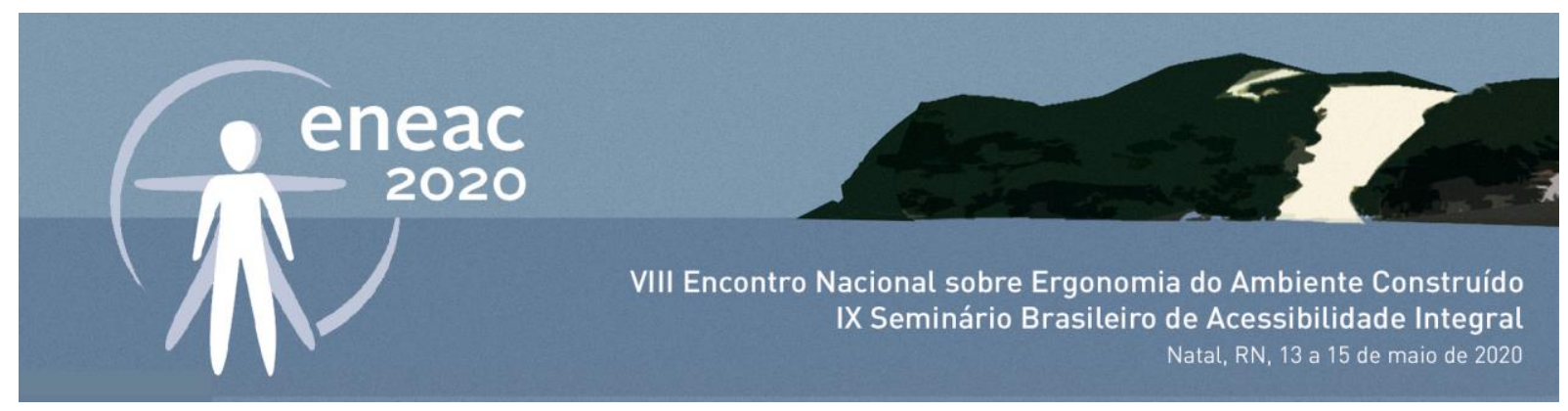

espaços utilizando diferentes atributos compositivos, ao passo que o ambiente complemente a vida humana trazendo cor, forma e volume, de modo a preencher a própria existência.

Os aspectos negativos foram pouco mencionados. Como indicadores de insatisfação emergiram: desconforto ambiental - em particular, o térmico e o acústico; a desorganização; e, a carência de empregados. A relação desarmônica entre pessoa e as condições acústicas e térmicas dos ambientem transparecem-se em: "Não gosto de barulho de vizinho, porque mora muita criança no prédio, eles batem muito a bola [...]" (E10); e "Temos um clima bem quente no verão [...] tem dias que a gente está assim com a língua de fora" (E01). A distribuição desorganizada é associada à bagunça, gerando descontentamento, e, por vezes, também se liga ao sentimento de insegurança quanto a possíveis quedas - face ao elemento surpresa de um arranjo diferente do que está acostumado. Já os idosos que contratam suporte profissional mencionaram a falta de mão de obra qualificada e comprometida, por certo estimam dedicação, capricho, cordialidade e pontualidade.

\subsubsection{Atividades}

A investigação da rotina dos idosos entrevistados conduziu a categoria Atividades, organizada em atividades prazerosas, e, aquelas em que encontrem dificuldades. As atividades realizadas com frequência e que correspondem à sensação de bem-estar espelham-se nas ações de: refletir, rezar ou meditar. Além disso, os entrevistados gostam de assistir televisão, desenvolver atividades manuais, virtualmente conversar com familiares e amigos, e, descansar. As dificuldades relatadas associam-se ao dimensionamento inadequado, somado à questão do equilíbrio, como exposto em: "Não sou mais aquela que eu era [...] às vezes eu uso objetos para me ajudar a pegar os objetos no alto, como uma colher de pau [...] eu não tenho mais condição de usar uma escada [retrátil], eu tenho medo de me desequilibrar" (E13). Para Prado e Perracini (2011) o contexto da habitação deve ser amigável ao envelhecimento, permitindo o ajuste do ambiente às necessidade e preferências do idoso, de forma natural e espontânea, o que além de contribuir para sua segurança, enaltece seu senso de controle e autoeficácia, portanto, é fonte de conforto físico e emocional.

\subsubsection{Conforto}

Conforto e satisfação relacionam-se a um conjunto de atributos que devem ser avaliados de forma sistêmica, pois a percepção espacial é consequência das características humanas ao captar os estímulos ambientais (VIEIRA et al., 2019). Universo que é composto, portanto, por: conforto ambiental - acústico, lumínico e térmico, somado ao conforto ergonômico; e, ao conforto subjetivo.

A noção de conforto relatada pelos entrevistados alinha-se com a perspectiva desses autores. Os participantes estão satisfeitos com a habitação em que residem, porém um terço da amostra já realizou reformas e readequações no ambiente doméstico, pois almejavam o conforto ergonômico e a segurança ao realizar as atividades da vida diária. Tais objetivos se materializam na instalação de barras de apoio em banheiro, demostrando consciência e valorização da acessibilidade. Além disso, um participante, promoveu o rearranjo espacial, em que o pavimento térreo de sua casa passou a abrigar sua suíte, que anteriormente ficava no pavimento superior acessado por meio de escada.

O conforto ergonômico também foi mencionado no que tange ao mobiliário e ao dimensionamento ambiental. A agradabilidade de mobiliários, como sofá e cama, é enaltecida pelo fato de comporem a ambiência de espaços em que os idosos mais gostam de estar, e, cuja permanência é longa. Isso é, o mobiliário deve estar adequado às características antropométricas e biomecânicas dos usuários 


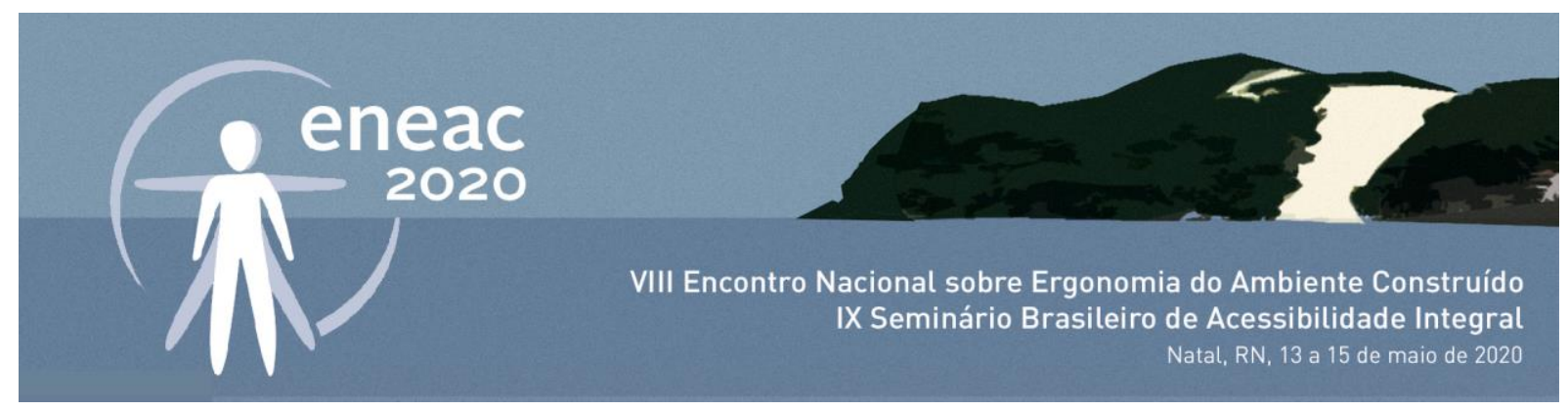

idosos. Já o conforto dimensional espelha-se em três preferências: (1) ambientes amplos, o que pode ser interpretado como a necessidade de espaço para a disposição de mobiliário e/ou circulações sem obstáculos ao deslocamento; (2) arranjo espacial que possibilite tudo estar próximo às mãos; e (3) provisão de eletroeletrônicos e tecnologias, a exemplo de televisão, computador e internet.

A compreensão de conforto também foi relacionada aos aspectos físico-ambientais relativos às questões térmicas, cujos momentos de descontentamento predominantemente vinculam-se à sensação de calor. Especialmente no verão, tal situação pode corresponder à indisposição e ao malestar. Corroborando com o quesito conforto ambiental, também foram abordados os tópicos: boa orientação solar, boa ventilação natural e luz indireta ou difusa. Expressões que indicam a correlação entre saúde e arquitetura da habitação, bem como a necessidade de conforto visual para realização de tarefas. Deve-se compensar a possível perda visual, particularmente ao distinguir cores e desníveis, bem como promover adaptação ao contraste entre claro e escuro. $O$ cruzamento das falas leva a especulação de que a valorização da amplitude, possa além de relacionar-se ao anseio de uma iluminação eficiente, associar-se à sensação de enclausuramento que pode ser suscitada por ambientes pequenos ou com obstáculos ao campo visual.

Por meio do questionamento sobre a noção de conforto emergiu um panorama de peculiaridades, que revelam o apreço por: lazer e convívio familiar e social; contato com a natureza; e, liberdade de ir e vir. Quadro ilustrado em: "[...] a liberdade de eu poder sair, ir no quintal, mexer numa terra [...] ligar para uma amiga, conversar com ela ali fora com o sol [...] isso é o que torna para mim agradável a minha casa" (E02); e "Um espaço de lazer, um belo de um salão de festas, um belo espaço para ginástica, uma quadra, jardim para os netos brincarem" (E06). Os laços afetivos manifestam-se, ainda, em objetos pessoais, como atestado em "[...] as bisnetas que estão ali [porta-retratos]" (E15). Além disso, o conforto subjetivo associa-se a objetos religiosos, como evidencia a fala "[...] eu gosto de estar com Deus no meu lar [...] tenho as minhas estátuas [...]" (E08). Portanto, registra-se a influência das emoções na percepção ambiental, em que as memórias, por vezes, expressam-se na forma de nostalgia, a exemplo do Entrevistado 10 que lamenta ter deixado sua antiga residência em razão da ocorrência de furtos, pois "gostaria de voltar a morar em uma casa térrea, com pátio".

\subsubsection{Futuro}

As entrevistam apresentam uma tapeçaria com a trama dos diferentes momentos da vida pessoal dos participantes e de sua família e, também, as diferentes habitações que acompanharam as fases de sua existência. Constatou-se que o dinamismo da vida se exprime nas modificações da residência e de seus ambientes, ao passo que como abordado na categoria conforto, apesar dos entrevistados relatarem satisfação quanto ao seu lar, 5 dos 15 participantes realizaram reformas ou readequações.

A imprevisibilidade da vida, particularmente, diante do processo de envelhecimento, instiga reflexões quanto ao futuro. Alguns entrevistados manifestaram resistência às mudanças, em que seu próprio futuro corresponde a " algo que não está no horizonte, mas a gente vai chegar um dia e vai ter que pensar" (E02). Os sentimentos de insegurança e de inquietude quanto à autonomia e à independência podem ser inferidos em depoimento como: "O dia que eu não puder mais fazer as coisas sozinha, eu não sei como é que vai ser [...] é a única coisa que [...] me deixa nervosa e irritada" (E15). Além dos rumos da própria existência, constatou-se a preocupação com cônjuge, familiar ou amigo, como relatado em: "Depois de estar casado [...] há 65 anos, não gostaria de ter nenhuma mudança daqui para frente" (E14). 


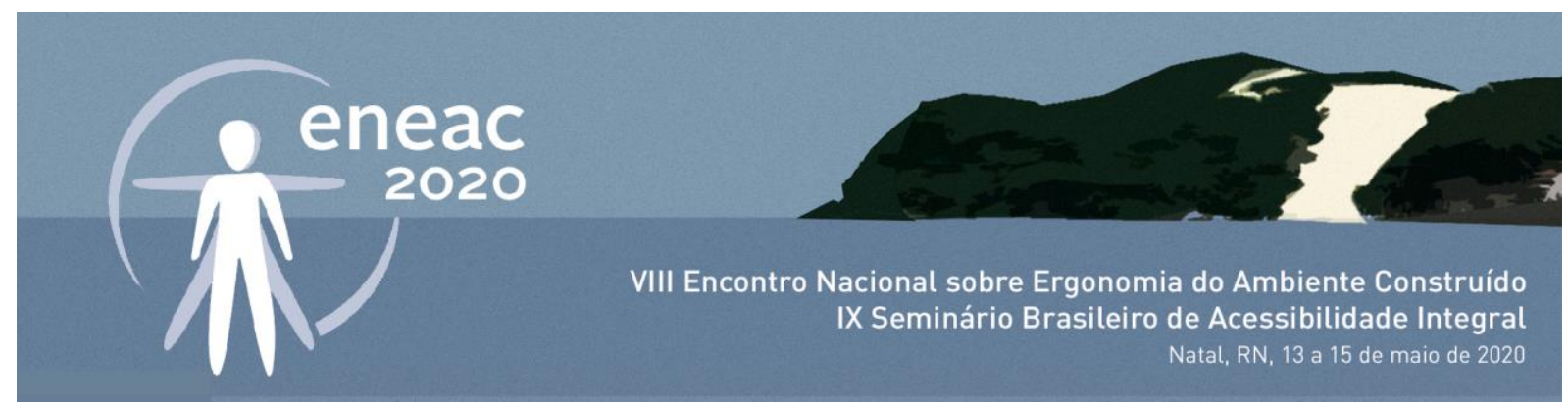

Em contrapartida, embora estejam satisfeitos com sua residência atual, houve relatos em que a hipótese de realocação foi cogitada, refletindo-se em diferentes possibilidades de habitação e formas de habitar, almejando maior suporte. Essa realidade ratifica a percepção de mudança positiva, pois como indica Golant (2011) tal realocação representa maior adequação às necessidades dos idosos e maior oferta de diferentes possibilidades de suporte.

Nesse espectro, as preocupações dos participantes com a manutenção da habitação e sua localização podem ser expressas em: "Daqui alguns anos, o que importa é que esteja bem localizado. [...] com fácil acesso, que eu possa sair, ali tem um supermercado [...] talvez um espaço menor do que eu vivo hoje, sem me limitar de transitar" (E02). Por vezes, os aspectos mencionados na categoria preferência são revistos, pois os ambientes amplos, com o avanço do processo de envelhecimento e possíveis dificuldades na realização de atividades da vida diária, podem ser interpretados como uma desvantagem. Fato esse que ao exigir manutenção com limpeza e organização, pode levar a dependência de terceiros ou reduzir tempo dedicado às atividades mais agradáveis. $O$ suporte no tocante ao entorno, se traduz na inserção da residência no contexto urbano, considerado por Coelho (2009) uma extensão do habitar. A localização da residência, de acordo com os entrevistados, traz segurança e comodidade ao estar próxima: aos familiares e amigos, e, aos centros de compra, assim como aos estabelecimentos com oferta de serviços em geral e também aos de assistência à saúde.

Ao refletir sobre a habitação em seu futuro, imaginando a possibilidade de realocação, observou-se o interesse por morar em comunidades, hotéis ou complexo habitacional para idosos independentes. Isso transparece o poder aquisitivo da amostra, que tem liberdade financeira para escolher: onde morar, com quem morar, bem como cobrir custos relativos à assistência quando solicitado ou necessário. Quadro demonstrado em: "O ideal seria um apart-hotel com um dormitório só, que tivesse todos os serviços [...] tem que ter alguém que levante a gente de um tombo [...]" (E06); "Penso até morar em um hotel, para poder ser bem servido" (E09); e "Eu moraria em uma comunidade, mas se eu encontrasse pessoas com as quais eu tivesse afinidade" (E5).

Aliado a provisão de suporte, seja por visar maior comodidade ou por almejar amparo quando necessário, os entrevistados desejam a preservação de sua privacidade, sobretudo espelhada em dormitório individual. Há, também, o enaltecimento da autonomia e da liberdade de ir e vir, como expõe a fala "tem algumas coisas que me agradam mais, como quarto particular com banheirinho [...]. Eu acho indispensável tipo a gente poder sair a hora que quiser [...]" (E08).

Averiguou-se, ainda, o interesse por ambientes que promovam lazer ativo e contemplativo somado ao convívio interpessoal, e, a crítica aos modelos tradicionais de habitação com cuidados continuados. Convicções que são compartilhadas na sequência. Para o Entrevistado 09, é agradável "pegar a bicicleta e andar pela orla, vendo as pessoas [...] Seria bom uma construção perto da praia [...]". Já a Entrevistada 08 ressalta que " Em uma casa de repouso tem uma sala enorme com televisor [...] Mas aquele monte de velho lá...Ah! É triste. Era para ter uma atividade para distração [...] que sempre tenha alguém fazendo uma brincadeira [...] coisas recreativas. Porque ficam parados demais."

Ao concatenar os aprendizados resultante das entrevistas, compreende-se que a variedade de hábitos, valores e preferências se liga à diversidade humana que também se revela no processo de envelhecimento. Essa heterogeneidade é um importante fator a ser considerado no processo de projeto, em que o conceito de habitabilidade conduza ao bem-estar e qualidade de vida. 


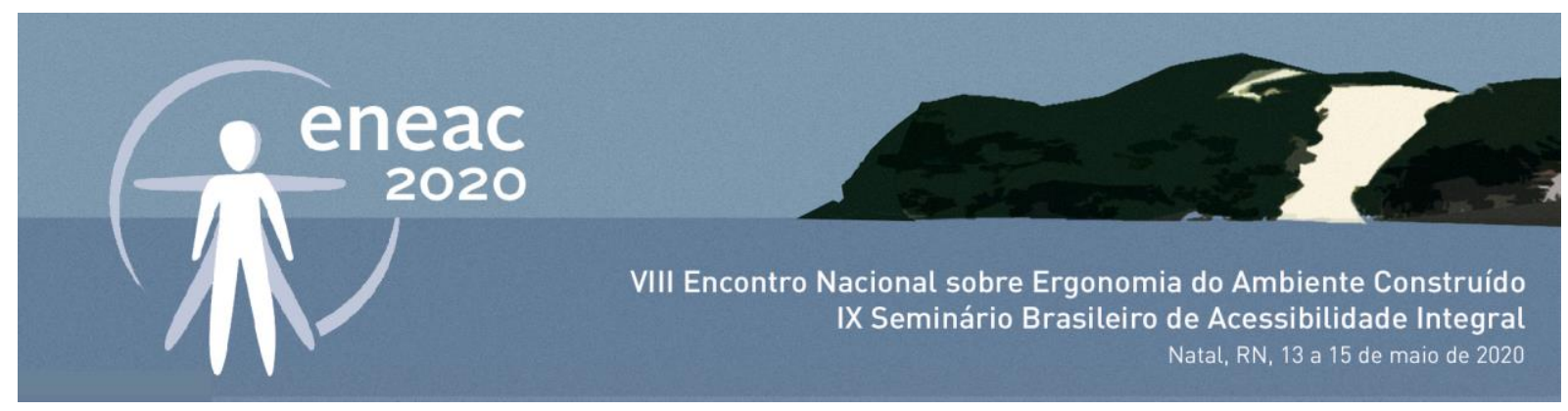

\section{CONSIDERAÇÕES FINAIS}

Face à atual trajetória de envelhecimento em que cresce o número de idosos, bem como amplia-se a expectativa de vida, este artigo debruça-se sobre a relação entre pessoa acima dos 60 anos e sua habitação. A relevância desta pesquisa norteia-se pelo entendimento de que o ambiente residencial é o de maior permanência nessa fase da vida e, que por sua íntima inter-relação com o usuário, não deve se restringir apenas a quatro paredes.

Arquitetos, designers e engenheiros devem, no processo de projeto de habitações, ter consciência dos atributos espaciais que proporcionem ao idoso bem-estar e conforto, aqui compreendidos como conjunto de aspectos simbólicos, funcionais e técnicos. Para isso, como abordado neste artigo, um dos caminhos é ouvir o usuário, pois é essencial compreender as atividades que compõem a rotina dos idosos, bem como a sua percepção de qualidade da habitação e de vida.

Este estudo envolveu quinze idosos com residência em área urbana, idade entre 60 e 90 anos, de ambos os gêneros, aposentados ou pensionistas, pertencentes às classes sociais A e B. Embora essa amostra seja bastante diversificada quanto à faixa etária, gênero e estado civil, existe uma uniformidade: os idosos entrevistados possuem boas condições de saúde, autonomia e independência. Acredita-se que as características sociais, culturais, econômicas e de saúde podem influenciar a percepção e preferências, ressaltando-se que os resultados poderiam ser diferentes caso a pesquisa estivesse voltada, por exemplo, para idosos com dependência.

Com base nos resultados obtidos pode-se afirmar que, dentre o universo dos entrevistados, há o predomínio de satisfação quanto a sua residência. Contudo, um terço dos participantes realizaram reformas e readequações em sua habitação com a intenção de tornar os espaços adequados às necessidades que se evidenciaram com o processo de envelhecimento. Tais modificações buscam propiciar segurança e conforto, evidenciando-se a demanda por deslocamento livre de obstáculos e adequado para pessoas que utilizam muletas, andadores ou cadeiras de rodas, e, o uso de acessórios como barras de apoio.

Verificou-se, a preocupação com o risco de quedas, dentre outros acidentes e problemas de saúde. Devido a essas inseguranças e visando a possibilidade de suporte, vários entrevistados priorizam a localização de suas residências próxima aos familiares e aos amigos, assim como aos ambientes assistenciais de saúde. Nota-se, também, a propensão à localização da habitação em áreas urbanas centrais que possibilitem o deslocamento rápido a comércio e a serviços, particularmente, quando dispensam o uso de automóveis.

Além da acessibilidade espacial, inserção urbana e manutenção da rede social e rede de apoio, as preferências dos idosos se manifestam em outros âmbitos, em que a noção de aconchego e conforto associa-se ao conforto ambiental, ergonômico e subjetivo. Como indicadores de conforto ambiental destacam-se, nas entrevistas realizadas, a inclinação por temperatura agradável. Portanto, indica-se a incorporação de estratégias de projeto que tirem partido da orientação solar e da ventilação natural. As transformações sensoriais próprias do envelhecimento, se espelharam na sensibilidade auditiva, principalmente no caso de apartamentos inseridos em edifício de habitação multifamiliar, em que ambientes de uso coletivo, como quadras desportivas, parque infantil e estacionamento, podem se configurar como fontes de ruído excessivo. No espectro das questões relativas ao conforto visual evidencia-se o gosto pela luz difusa ou indireta, o que demonstra a sensibilidade ao ofuscamento. Pode-se, ainda, inferir que o apreço por ambientes amplos e sem poluição visual esteja arraigado na necessidade de níveis de luminância adequados à realização de atividades e no desejo de segurança 


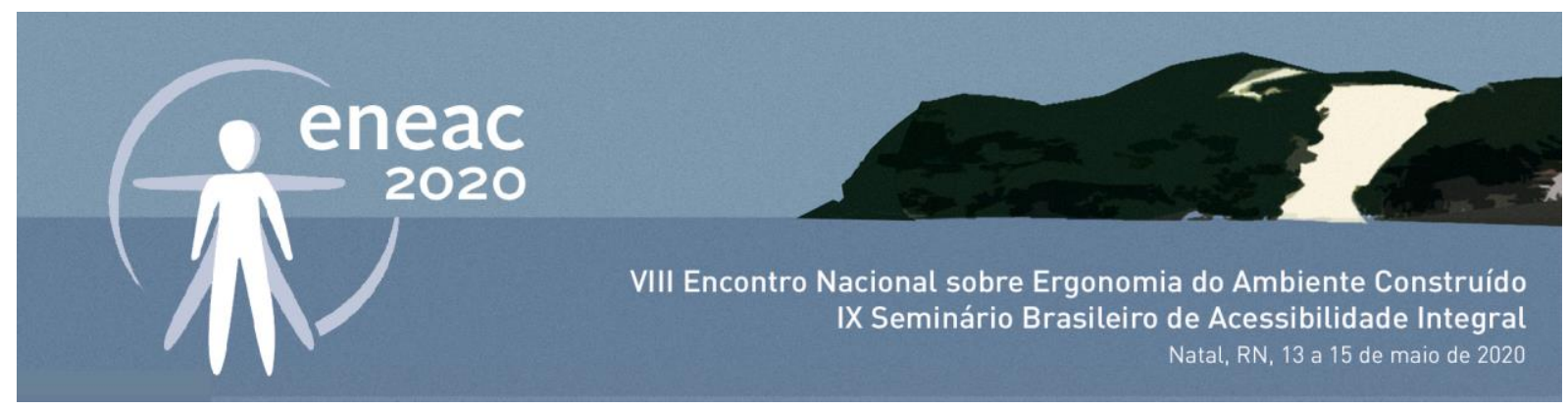

ao evitar acidentes. Já o conforto ergonômico se reflete em equipamentos e mobiliários que fazem parte da rotina da maioria dos entrevistados, com ênfase em mobiliários como sofás e camas, e, eletroeletrônicos como televisão e computador. Cabe mencionar, ainda, o conforto subjetivo expresso em laços afetivos com objetos pessoais e decorativos, a exemplo de símbolos religiosos, e, porta-retratos que expõem fotografias de amigos e familiares. Outro aspecto relevante é a valorização da relação com a natureza, que pode ocorrer de duas formas: indireta - contato visual com paisagens; ou direta - pátios, jardins, elementos naturais inseridos em artefatos decorativos etc. Verificou-se o autoquestionamento, anterior às entrevistas, por parte dos idosos sobre a habitação em seu próprio futuro. Notou-se o anseio por formas de habitar que ofereçam suporte ao envelhecimento, concomitantemente ao desejo de maximizar: autonomia, independência, privacidade, liberdade de ir e vir, prática de atividades de lazer, manutenção dos relacionamentos afetivos e convívio social, somado à integração com a natureza e à conexão com a cidade.

Os resultados desta pesquisa não podem ser generalizados, mas ao trazer reflexões colabora para soluções espaciais residenciais mais adequadas ao usuário idoso. Não há uma resposta única de habitação ideal para o idoso ativo e saudável, pois é possível compor diferentes arranjos espaciais que contribuam para sua a qualidade de vida e seu bem-estar. Entretanto, os parâmetros mínimos quantificáveis devem ser ultrapassados por uma visão sensível, em que o olhar sobre o habitar seja ampliado, incorporando os vínculos de apego e de afetividade, assim como a relação com a natureza e com o contexto urbano e sociocultural.

\section{REFERÊNCIAS}

BACHELARD, G. A poética do espaço. São Paulo: Fontes, 2000.

BARDIN, L. Análise de conteúdo. São Paulo: Edições 70, 2011.

BINS ELY, V. H. M. A moradia está adequada às necessidades do idoso? In: IV Workshop de análise ergonômica do trabalho e I Encontro mineiro de estudos de ergonomia, 2009. Viçosa. Anais [...]. Viçosa: UFG, 2009.

BINS ELY, V.H.M.; MASSON, O. Instituição para idosos: Ambiente saudável? Revista Ergodesign HCl, v.5, n.1, p. 60-70, 2017.

BRANDÃO, D. Q.; HEINECK, L. F. M. Significado Multidimensional e Dinâmico do Morar: compreendendo as modificações na fase de uso e propondo flexibilidade nas habitações sociais. Ambiente Construído, v. 3, n. 4, p. 35-48, 2003.

BRASIL. Secretaria Nacional de Promoção e Defesa dos Direitos da Pessoa Idosa - SNDPI. Ministério da mulher, da família e dos direitos humanos. Programa Viver - Envelhecimento Ativo e Saudável. Publicado em 19 de março de 2019.

CARADEC, V. Da terceira idade a idade avançada: a conquista da velhice. In: GOLDENBERLG, M. (org.). Velho é lindo! $1^{\text {a }}$ ed. Rio de Janeiro: Civilização Brasileira, 2016, cap.1, p.11-38.

COELHO, A.B. Entre casa e cidade, a humanização do habita. Opúsculos - Pequenas Construções Literárias sobre Arquitectura, Porto, p. 2-19, 2009.

CONFORTIN, S.C. et al. Autopercepção positiva de saúde em idosos: estudo populacional no sul do Brasil. Cadernos de Saúde Pública, Rio de Janeiro, v. 31, n.5, p. 1049-1060, 2015.

ELALI, G. V. Mais do que paredes: algumas considerações sobre aspectos subjetivos da habitação. In: II CONGRESSO BRASILEIRO E I IBERO-AMERICANO DE HABITAÇÃO SOCIAL, 2006, Florianópolis. Anais [...]. Florianópolis: CTHab, 2006.

GITLIN, L.N. Conducting research on home environments: Lessons learned and new directions. The Gerontologist, v. 43, n.5, p.628-637, 2003.

GIULIANI, M. V. O lugar do apego nas relações pessoas-ambiente. In: TASSARA, E. O.; RABINOVICH, E. P.; GUEDES, M. C. (ed.). Psicologia e ambiente. São Paulo: EDUC, 2004, p.89-106. 


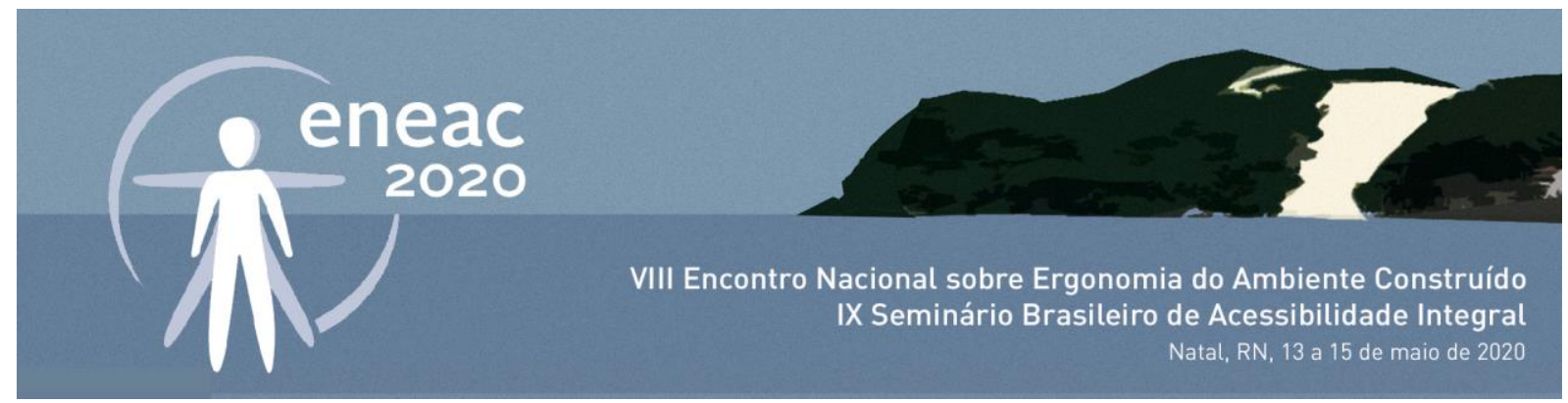

GOLANT, S. M. The changing residential environments of older people. In: BINSTOCK, R. H.; GEORGE, L. K. (ed.). Handbook of Aging and the Social Sciences. 7th edition. New York: Academic Press, 2011, p. 207-220.

HERTZBERGER, H. Lições de arquitetura. São Paulo: Martins Fontes, 1999.

HEYWOOD, F. Understanding needs: A starting point for quality. Housing Studies, v.19, n. 5, p.709-726, 2004.

HEYWOOD, F.; OLDMAN, C; MEANS, R. Housing and home in later life. Buckingham: Open University Press, 2002.

HUNT, M. E. The design of supportive environments for older people: Haworth Press. In: Congregate Housing for the elderly, 1991, p.127-139.

KALACHE, A. O mundo envelhece: é imperativo criar um pacto de solidariedade social. Ciência \& Saúde Coletiva, Rio de Janeiro, v. 13, n.4, p.1107-1111, 2008.

LEITH, K.H. 'Home is where the heart is...or is it?': A phenomenological exploration of the meaning of home for older women in congregate housing. Journal of Aging Studies, v.20, n. 4, p. 317-333, 2006.

MALARD, M. L. As aparências em Arquitetura. Belo Horizonte: Editora UFMG, 2006.

MASSON, O.; VANNESTE, D. Habitat et vieillissement: Inventaire des formes de logements qui supportent l'interdépendance et l'autonomie des seniors. Louvain - Belgique: Université Catholique de Louvain - UCL, 2015.

OLIVEIRA, A.S. et al. Fatores ambientais e risco de quedas em idosos: revisão sistemática. Revista Brasileira de Geriatria e Gerontologia, Rio de Janeiro, v. 17, n.3, p. 637-645, 2014.

PRADO, A. R.A.; PERRACINI, M. R. A construção de ambientes favoráveis aos idosos. In: NERI, A. L. (org.). Qualidade de vida na velhice: enfoque multidisciplinar. 2. ed. rev. Campinas: Alínea, 2011, p.221-229.

PYNOOS, J.; CICERO, C. New approaches to housing and aging in place. Public Policy \& Aging Report, v. 19, n. 1, p.03-08, 2009.

RAMOS, L. R. Fatores determinantes do envelhecimento saudável em idosos residentes em centro urbano: Projeto Epidoso. Cadernos de Saúde Pública, Rio de Janeiro, v. 19, n. 3, p. 793-798, 2003.

RHEINGANTZ; P. A. et al. Observando a qualidade do lugar: procedimentos para avaliação pós-ocupação. Rio de Janeiro: Universidade Federal do Rio de Janeiro, Faculdade de Arquitetura e Urbanismo, Pós-Graduação em Arquitetura, 2009.

SCHMID, A. L. A ideia do conforto: reflexões sobre o ambiente construído. Curitiba: Pacto Ambiental, 2005.

SHRAIKY, J. Prescribing Architecture: A Critical Evaluation of How Design Impacts Health and Wellness. Journal of Healthcare, Science and the Humanities, v.l, n.1, p.89-109, 2011.

SILVEIRA, C. M. F. Habitação de suporte para idosos: contribuição da arquitetura para o envelhecimento ativo e saudável. 2019. 386 f. Dissertação (Mestrado) - Universidade Federal de Santa Catarina, Centro Tecnológico, Programa de PósGraduação em Arquitetura e Urbanismo, Florianópolis, 2019.

SOMMER, R. Espaço pessoal: as bases comportamentais de projetos e planejamentos. São Paulo: Editora da Universidade de São Paulo, 1973.

ULRICH, R. S. Effects of interior design on wellness: Theory and recent scientific research. Journal of Health Care Interior Design, v. 3, n.1, p. 97-109, 1991.

VALER, D. et al. O significado de envelhecimento saudável para pessoas idosas vinculadas a grupos educativos. Revista Brasileira de Geriatria e Gerontologia, Rio de Janeiro, v. 18, n.4, p.809-819, 2015.

VIEIRA, E. M. A. et al. dos S. Prioridade perceptiva e critérios de satisfação de atributos ambientais em Unidades de Terapia Intensiva. Ambiente Construído, Porto Alegre, v. 19, n.1, p. 181-194, 2019.

WORLD HEALTH ORGANIZATION (WHO). Active Ageing - A Police Framework. Geneva: World Health Organization, 2002.

WORLD HEALTH ORGANIZATION (WHO). World report on ageing and health. Geneva: World Health Organization, 2015. 